\title{
ASSESSMENT OF RISK FACTORS AND EVALUATION OF MATERNOFOETAL OUTCOMES IN FOETAL GROWTH RESTRICTION- A CONTROLLED STUDY AT A TEACHING HOSPITAL IN SOUTH INDIA
}

\author{
Farheen Naazi1, Emmadisetty Swathi², Mohammed Ismail Khan ${ }^{3}$
}

1Department of Obstetrics and Gynaecology, ESIC Medial College, Sanathnagar, Hyderabad. 2Department of Obstetrics and Gynaecology, ESIC Medial College, Sanathnagar, Hyderabad. 3 Department of Obstetrics and Gynaecology, ESIC Medial College, Sanathnagar, Hyderabad.

\section{ABSTRACT}

\section{BACKGROUND}

Foetal Growth Restriction (FGR) is a relatively common, but dreaded obstetric and paediatric complication with adverse foetal and perinatal outcomes whose sequelae continue to haunt for a lifetime. Knowledge of predisposing factors and outcomes can help us manage these pregnancies and neonates in better ways.

\section{MATERIALS AND METHODS}

The study was conducted at ESIC Medical College Teaching Hospital over a period of two years; 116 cases were registered as FGR and suitable controls without FGR were selected. Risk factor occurrence, maternal outcomes, mode of delivery, neonatal characteristics, postnatal outcomes and perinatal mortality were recorded in both groups and compared by suitable statistical tests to assess the significance of observations noted.

\section{RESULTS}

Statistically significant relationship was observed between smoking, maternal malnutrition, pregnancy-induced hypertension, maternal anaemia and chronic infection (all significant with $\mathrm{p}<0.05$ ). A higher rate of caesarean section was observed in study group compared to control group ( $62 \%$ vs. $18.1 \%)$, which was significant $(\mathrm{p}<0.0001)$. Meconium stained liquor and reduced liquor was seen more in study group, 42 and 29 patients compared to 15 and 21 patients in control group, respectively. Still births occurred to the tune of $8.6 \%$ in study group. Mean birth weight was $2105 \pm 50$ gms at mean gestational age $36.6 \pm 1.2$ weeks in FGR foetuses compared to $2850 \pm 107 \mathrm{gm}$ at $38.9 \pm 0.6$ weeks in foetuses without FGR. Respiratory distress syndrome (P -0.007$)$, Necrotising enterocolitis (P - 0.03), Sepsis (P - 0.01) and Retinopathy of prematurity (P - 0.04) were more common in study group versus control group. Perinatal mortality was 20.75\% (22 babies) in FGR group compared to 0.9\% (3 babies) in control group (P < 0.0001).

\section{CONCLUSION}

FGR adversely affects the foetus and neonate. In light of recent evidence, there has been an emphasis on life-term risks in babies born with FGR. The psychological trauma on the mother to have a child with FGR and to raise it is enormous, herculean and heart breaking. An understanding of predisposing factors and outcomes can help us better predict pregnancy outcomes in these cases in clinical settings.

\section{KEYWORDS}

Foetal Growth Restriction, Small for Gestational Age, Foetal Surveillance, Still Births, Perinatal Mortality.

HOW TO CITE THIS ARTICLE: Naaz F, Swathi E, Khan MI. Assessment of risk factors and evaluation of maternofoetal outcomes in foetal growth restriction - a controlled study at a teaching hospital in South India. J. Evolution Med. Dent. Sci. 2017;6(20):15601565, DOI: $10.14260 / \mathrm{Jemds} / 2017 / 343$

\section{BACKGROUND}

The Royal College of Obstetricians and Gynaecologists (RCOG) defines Small for Gestational Age (SGA) foetus as foetal Abdominal Circumference (AC) or Estimated Foetal Weight (EFW) less than $10^{\text {th }}$ centile [a]. The RCOG further classifies SGA foetuses into constitutionally small and Foetal Growth Restriction (FGR).

FGR represents a severe pathological affliction of foetal growth, whereas SGA also constitutes constitutionally small babies apart from FGR. Hence, FGR can be differentiated from SGA by oligohydramnios and/or foetal Doppler changes.

Financial or Other, Competing Interest: None.

Submission 30-01-2017, Peer Review 24-02-2017,

Acceptance 01-03-2017, Published 09-03-2017.

Corresponding Author:

Dr. Mohammed Ismail Khan,

\#16-9-408/P/83,

Wahed Nagar, Old Malakpet,

Hyderabad-500036, Telangana.

E-mail: drismailobg@gmail.com

DOI: $10.14260 /$ jemds $/ 2017 / 343$
The RCOG describes Umbilical Artery (UA) Doppler as the primary surveillance tool in SGA foetuses.[1] FGR is hence being described as AC or EFW less than $3^{\text {rd }}$ centile or less than $10^{\text {th }}$ centile with Doppler changes and/or oligohydramnios, whereas SGA being described as EFW or AC more than $3^{\text {rd }}$ centile and less than $10^{\text {th }}$ centile with normal Doppler studies.[2,3] Abnormal Doppler changes are defined as pulsatility or resistance index more than 2SD above the mean for Gestational Age (GA) in UA.[1]

The development of FGR is determined by maternal, foetal and placental factors. Many of these factors are preventable like smoking, alcohol abuse, infections, pregnancy-induced hypertension (PIH), maternal malnutrition, assisted reproductive techniques and multifoetal gestation. ${ }^{[4]}$

FGR predisposes a foetus to adverse outcomes in foetal, neonatal and infantile periods, whose sequelae continue well into childhood and adulthood. Perinatal mortality has increased in FGR foetuses and new-borns.[5] A modern classification system of stillbirth, ReCoDe has shown that FGR 
is the most common factor identified in stillborn babies. In addition, it has serious consequences for babies who survive.

FGR is associated with increased risk of premature birth, increased morbidity among premature neonates including necrotising enterocolitis, low APGAR score, hypoxic brain injury and its long-term sequelae, the need for respiratory support and chronic lung disease, retinopathy of prematurity, prolonged Neonatal Intensive Care Unit (NICU) care and mortality.[6] Furthermore, a number of causes of FGR are associated with an increased risk of FGR and intrauterine death in mother's subsequent pregnancy.[7] Such infants are also at a higher risk of sepsis because of a compromised immune system. In long-term, babies born with FGR are shorter and lighter and more likely to be diagnosed with cerebral palsy and have a lower Intelligence Quotient.[8]

The high incidence of FGR in general obstetric population $(\sim 10 \%)$ and its low recognition $(<40 \%)$ together lead to increasing perinatal morbidity and mortality. ${ }^{[9]}$ More so in a developing country like India where predisposing risk factors occur at high levels in mothers.

\section{Objectives}

FGR poses a life-threatening challenge to the foetus in-utero, which could lead to bad obstetric consequences and undesirable perinatal outcomes. The study aims at evaluating the risk factors and materno-foetal outcomes in mothers with FGR in comparison to matched controls. Knowledge of modifiable risk factors could reduce the incidence of FGR and a study of outcomes could help in better management.

\section{MATERIALS AND METHODS}

The study was conducted as a prospective comparative study at ESIC Medical College Hospital over a period of two years from 2015 - 2017. ESIC Medical College Hospital is a tertiary care teaching hospital catering to obstetric referrals from 35 ESIC Hospitals and Dispensaries, in addition to its own patients.

Antenatal mothers who presented for regular antenatal check-up were considered for the study. Approval was obtained from the Institutional Ethics Committee and subjects and controls were recruited only after informed consent.

A 30 weeks, third trimester scan was considered for assessment of foetal growth. The study group consisted of 116 mothers diagnosed with EFW less than $3^{\text {rd }}$ centile or less than $10^{\text {th }}$ centile with foetal UA Doppler changes or oligohydramnios. Suitably 116 women were taken as controls after matching age, parity and GA whose EFW was more than $10^{\text {th }}$ centile and less than $90^{\text {th }}$ centile. Socioeconomic status was not matched as ours being a Government hospitals, all patients come from similar background. Foetal growth chart proposed by Kramer and coherent with WHO Growth standards version were used in the study.[10]

Questionnaire method was followed for literate patients and interview was done for uneducated patients, for risk factor assessment apart from a thorough clinical history and review of antenatal records. Risk factors like cord and placental pathology were assessed after the delivery. Patients were followed up closely with repeat Ultrasonographic (USG) examination for foetal morphometric analysis. Foetal surveillance was performed by UA Doppler in accordance with RCOG Guidelines.[1] Middle Cerebral Artery (MCA) Doppler, Cardiotocography (CTG) and Biophysical profile were not considered for foetal assessment in accordance with
RCOG guidelines.[1] Ductus venosus and Umbilical Vein Doppler could not be performed due to technical shortcomings.

Abnormal UA Doppler with Absent or Reduced End Diastolic Velocities (AREDV) detected before 32 weeks were delivered before 32 weeks; those with UA Doppler with AREDV detected after 32 weeks were delivered before 37 weeks. Any foetus with abnormal MCA Doppler was delivered before 37 weeks. Mode of delivery was determined by EDV in UA. Foetuses who presented with presence of UA-EDV were allowed to set spontaneously or given induction with Electronic Foetal Monitoring (EFM) and those with UAAREDV were taken for emergency caesarean section.

Data regarding intrapartum foetal surveillance and obstetric outcomes was recorded. After birth the neonate was carefully assessed and anthropometric findings and APGAR scores were recorded. Those with a compromised state were admitted to NICU and were thereafter followed by a paediatrician. These babies were also followed up to 1 week and findings were noted. The data was tabulated and statistically evaluated by Social Science and GraphPad online Software.

\section{Selection Criteria for Study Group}

1. Patients between 18 - 40 years of age.

2. Spontaneous conception.

3. EFW and/or AC less than $10^{\text {th }}$ centile with signs of foetal compromise.

4. EFW and/or AC less than 3 rd centile.

5. Foetal viability at the time of diagnosis.

6. Known and unknown GA at the time of presentation.

\section{Selection Criteria for Comparison Group}

1. Age, parity and GA matched to the case.

2. EFW and/or AC greater than $10^{\text {th }}$ centile, but less than $90^{\text {th }}$ centile.

3. Absence of pre-existing medical disorders.

4. Absence of obstetric disorders or factors complicating pregnancy.

5. Occurrence of FGR or any other obstetric disorder during pregnancy.

\section{Research involving Human Participants}

- All procedures performed on the patient were in accordance with the ethical standards of the Institutional and National Research Committee and with the 1975 Helsinki declaration and its latest amendment in 2000 and other comparable ethical standards.

- All treatment protocols followed are in accordance with the latest accepted Evidence Based Medicine Norms of the RCOG.

- Foetal sex was neither detected nor informed in accordance with the PNDT Act 1994.

\section{RESULTS}

There were 7,256 admissions to the labour room in the past 2 years, which brings the incidence of SGA to $17.9 \%$ and true FGR to $1.25 \%$. As shown in Table 1, differences in demographic details of the study and control group are statistically insignificant, as they were appropriately matched for age, parity, gestational week and socioeconomic status and hence comparable. The highest incidence of FGR occurs in 21 - 25 years (45.6\%), Primis (44.8\%) at $36-37$ weeks gestation $(31.89 \%)$. This is statistically significant in the sample studied by goodness of fit. 


\begin{tabular}{|c|c|c|c|c|c|c|c|}
\hline \multicolumn{6}{|c|}{ Distribution of Age } & & \\
\hline Age & $<20$ yrs. & 21 - 25 yrs. & 26 - 30 yrs. & 31 - 35 yrs. & $>35$ yrs. & P value $^{\dagger}$ & P value $\neq$ \\
\hline $\begin{array}{l}\text { Frequency in Study } \\
\text { group }(\mathrm{N}=116)\end{array}$ & 11 & 53 & 34 & 13 & 5 & $<0.001^{*}$ & \multirow{2}{*}{$0.99 \neq$} \\
\hline $\begin{array}{l}\text { Frequency in Control } \\
\text { group }(\mathrm{N}=116)\end{array}$ & 10 & 56 & 36 & 11 & 3 & $<0.001^{*}$ & \\
\hline \multicolumn{6}{|c|}{ Distribution of Order of Birth } & & \\
\hline Parity & Primi & Gravida 2 & Gravida 3 & Gravida 4 & Grand Multi & $\mathrm{P}_{\text {value }}{ }^{\dagger}$ & \\
\hline $\begin{array}{l}\text { Frequency in Study } \\
\text { group }(\mathrm{N}=116)\end{array}$ & 52 & 34 & 16 & 10 & 4 & $<0.001^{*}$ & \multirow{2}{*}{$0.63 \neq \neq$} \\
\hline $\begin{array}{l}\text { Frequency in Control } \\
\text { group }(\mathrm{N}=116)\end{array}$ & 56 & 36 & 17 & 5 & 2 & $<0.001^{*}$ & \\
\hline \multicolumn{6}{|c|}{ Distribution of Age at Presentation } & & \\
\hline Gestational Age & $\begin{array}{l}30^{+0} \text { wks to } \\
31^{+6} \text { wks }\end{array}$ & $\begin{array}{c}32^{+0} \text { wks to } \\
33^{+6} \text { wks }\end{array}$ & $\begin{array}{c}34^{+0} \text { wks to } 35^{+6} \\
\text { wks }\end{array}$ & $\begin{array}{c}36^{+0} \text { wks to } 37^{+6} \\
\text { wks }\end{array}$ & $\begin{array}{c}38^{+0} \text { wks to } 39^{+6} \\
\text { wks }\end{array}$ & $\mathrm{P}_{\text {value }}^{\dagger}$ & \\
\hline $\begin{array}{l}\text { Frequency in Study } \\
\text { Group }(\mathrm{N}=116)\end{array}$ & 16 & 20 & 24 & 37 & 19 & $<0.001^{*}$ & \multirow{2}{*}{1 玤 } \\
\hline $\begin{array}{l}\text { Frequency in Control } \\
\text { Group }(\mathrm{N}=116)\end{array}$ & 16 & 20 & 24 & 37 & 19 & $<0.001^{*}$ & \\
\hline
\end{tabular}

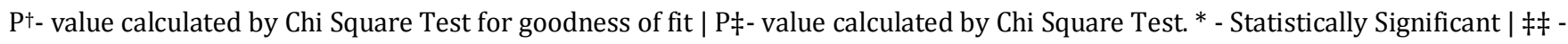
Statistically insignificant.

Table - 2, illustrates the aetiologic relationship between various predisposing risk factors and FGR. Maternal malnutrition appears to be significantly related with FGR (P $<0.0001$ ); $8.6 \%$ of study group had exposure to tobacco smoke compared to $2.5 \%$ in control group, which appears statistically significant $(P-0.04)$. Acute febrile infections in the mother had no effect on foetal growth, whereas chronic infections in the mother significantly restricted foetal growth (P - 0.46 and $\mathrm{P}-0.01$ respectively). Placental and cord pathology were seen in 9 and 13 patients respectively in FGR group compared to 2 and 5 patients respectively in control group (statistically significant in both cases with $\mathrm{p} 0.03$ and 0.04 respectively). Alcoholism does not appear to be a risk factor statistically, which could be due to very low incidence of alcoholism in women in our community. PIH $(25 \%$ - P 0.003 ) and Anaemia (26.7\% - P 0.05) in the FGR group appears to significantly increase the risk of foetal growth aberrations.

\begin{tabular}{|c|c|c|c|c|c|c|}
\hline Sl. No. & Risk Factor & $\begin{array}{c}\text { Risk Factor } \\
\text { Characterisation }\end{array}$ & $\begin{array}{c}\text { Study Group } \\
\text { FGR } \\
(\mathrm{N}=116) \text { n (\%) }\end{array}$ & $\begin{array}{c}\text { Control Group } \\
\text { No FGR } \\
(\mathrm{N}=116) \text { n (\%) }\end{array}$ & $P^{\dagger}$ - value & $\begin{array}{c}\text { Relative } \\
\text { Risk }\end{array}$ \\
\hline \multirow{2}{*}{1.} & \multirow{2}{*}{$\begin{array}{c}\text { Smoking } \\
\text { (Active and/or Passive) }\end{array}$} & No Smoking & $106(91.3 \%)$ & $113(97.4 \%)$ & \multirow{2}{*}{$0.04^{*}$} & \multirow{2}{*}{1.58} \\
\hline & & Smoking & $10(8.6 \%)$ & $3(2.5 \%)$ & & \\
\hline \multirow{2}{*}{2.} & \multirow{2}{*}{ Alcoholism } & No Alcoholism & $111(95.6 \%)$ & $113(97.4 \%)$ & \multirow{2}{*}{0.47 㧊 } & \multirow{2}{*}{1.25} \\
\hline & & Alcoholism & $5(4.3 \%)$ & $3(2.5 \%)$ & & \\
\hline \multirow{2}{*}{3.} & \multirow{2}{*}{$\begin{array}{l}\text { Antenatal } \\
\text { Care }\end{array}$} & Booked & $69(59.4)$ & $61(52.5 \%)$ & \multirow{2}{*}{0.28 㧊 } & \multirow{2}{*}{0.86} \\
\hline & & Unbooked & $47(40.5 \%)$ & $55(47.4 \%)$ & & \\
\hline \multirow{2}{*}{4.} & \multirow{2}{*}{$\begin{array}{c}\text { Maternal } \\
\text { Malnutrition }\end{array}$} & $\mathrm{BMI}>18.5 \mathrm{~kg} / \mathrm{m}^{2}$ & $73(62.9 \%)$ & $99(85.3 \%)$ & \multirow{2}{*}{$<0.0001^{*}$} & \multirow{2}{*}{1.68} \\
\hline & & $\mathrm{BMI}<18.5 \mathrm{~kg} / \mathrm{m}^{2}$ & $43(37 \%)$ & $17(14.6 \%)$ & & \\
\hline \multirow{2}{*}{5.} & \multirow{2}{*}{$\begin{array}{l}\text { Pregnancy Induced } \\
\text { Hypertension (PIH) }\end{array}$} & No PIH & $87(75 \%)$ & $104(89.6 \%)$ & \multirow{2}{*}{$0.003^{*}$} & \multirow{2}{*}{1.55} \\
\hline & & $\mathrm{PIH}$ & $29(25 \%)$ & $12(10.3 \%)$ & & \\
\hline \multirow{2}{*}{6.} & \multirow{2}{*}{ Maternal Anaemia } & No Anaemia & $85(73.2 \%)$ & $97(78.4 \%)$ & \multirow{2}{*}{$0.05^{*}$} & \multirow{2}{*}{1.32} \\
\hline & & Anaemia & $31(26.7 \%)$ & $19(16.3 \%)$ & & \\
\hline \multirow{2}{*}{7.} & \multirow{2}{*}{ Placental Pathology (PcP) } & No PcP & $107(92.2 \%)$ & $114(98.27 \%)$ & \multirow{2}{*}{$0.03 *$} & \multirow{2}{*}{1.68} \\
\hline & & PcP Present & $9(7.7 \%)$ & $2(1.7 \%)$ & & \\
\hline \multirow{2}{*}{8.} & \multirow{2}{*}{ Cord Pathology (CoP) } & No CoP & $103(88.7 \%)$ & $111(95.6 \%)$ & \multirow{2}{*}{$0.04^{*}$} & \multirow{2}{*}{1.50} \\
\hline & & CoP Present & $13(11.2 \%)$ & $5(4.3 \%)$ & & \\
\hline \multirow{2}{*}{9.} & \multirow{2}{*}{ Chronic Infection (CoI) } & No CoI & $100(86.2 \%)$ & $111(95.6 \%)$ & \multirow{2}{*}{$0.01 *$} & 160 \\
\hline & & CoI Present & $16(13.8 \%)$ & $5(4.3 \%)$ & & 1.60 \\
\hline 10 & Acuto Infoction (AcI) & No AcI & $81(69.8 \%)$ & $86(74.1 \%)$ & $046+t$ & 111 \\
\hline 10. & Acute Infection (Acl) & AcI & $35(30.1 \%)$ & $30(25.8 \%)$ & $0.46^{\neq \neq}$ & 1.11 \\
\hline
\end{tabular}

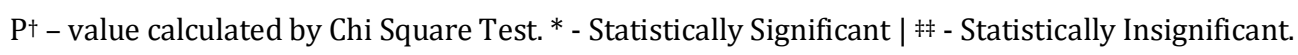


Obstetric Outcomes are tabulated in Table 3, intrapartum foetal monitoring in labour with cardiotocography shows a higher percentage of foetuses (60 vs. 21) in FGR group had non-reassuring pattern $(\mathrm{P}<0.0001)$. Colour of liquor shows statistically significant differences between FGR and non-FGR groups, thereby signifying that liquor characteristics can be used for intrapartum monitoring. Morbidity was more in mothers of study group due to operative interference, as caesarean section rate was at $62 \%$ in them compared to $18.1 \%$ in control group ( $\mathrm{P}<0.0001) ; 10$ still births were recorded in FGR babies (8.6\%) compared to 2 still births in non-FGR babies $(1.7 \%)$ and this association was significant with $\mathrm{P}$ value of $0.03 ; 12$ babies in excess had neonatal asphyxia in study group with $\mathrm{P}-0.15$. Figure 1 represents the mode of delivery in study group.

\begin{tabular}{|c|c|c|c|c|c|}
\hline $\begin{array}{l}\text { Sl. } \\
\text { No. }\end{array}$ & Outcome & $\begin{array}{c}\text { Outcome } \\
\text { Characterisation }\end{array}$ & $\begin{array}{c}\text { Study Group } \\
\text { FGR } \\
(\mathrm{N}=116)\end{array}$ & $\begin{array}{c}\text { Control Group } \\
\text { No FGR } \\
\text { (N=116) }\end{array}$ & $\mathrm{P}^{\dagger}-$ value \\
\hline \multirow{2}{*}{1.} & \multirow{2}{*}{ Cardiotocography (CTG) } & Reassuring & $56(48.2 \%)$ & $95(81.8 \%)$ & \multirow{2}{*}{$<0.0001^{*}$} \\
\hline & & Non-Reassuring & $60(51.7 \%)$ & $21(18.1 \%)$ & \\
\hline \multirow{4}{*}{2.} & \multirow{4}{*}{ Colour of Liquor } & Clear and Adequate & $26(22.4 \%)$ & $78(67.2 \%)$ & \multirow{4}{*}{$<0.0001^{*}$} \\
\hline & & Clear and Less & $29(25 \%)$ & $21(18.1 \%)$ & \\
\hline & & Meconium Stain & $42(36.2 \%)$ & $15(12.9 \%)$ & \\
\hline & & Nil liquor & $19(16.3 \%)$ & $2(1.7 \%)$ & \\
\hline \multirow{2}{*}{3.} & \multirow{2}{*}{ Mode of Delivery } & Vaginal & $44(37.9 \%)$ & $95(81.8 \%)$ & \multirow{2}{*}{$<0.0001^{*}$} \\
\hline & & Caesarean & $72(62 \%)$ & $21(18.1 \%)$ & \\
\hline \multirow{2}{*}{4.} & \multirow{2}{*}{ Neonatal Asphyxia } & No Asphyxia & $96(82.75 \%)$ & $108(93.1 \%)$ & \multirow{2}{*}{$0.15^{*}$} \\
\hline & & Asphyxia & $20(17.24 \%)$ & $8(6.89 \%)$ & \\
\hline \multirow{2}{*}{5.} & \multirow{2}{*}{ Still Births } & Live Born & $106(91.3 \%)$ & $114(98.2 \%)$ & \multirow{2}{*}{$0.03 *$} \\
\hline & & Still Born & $10(8.6 \%)$ & $2(1.7 \%)$ & \\
\hline
\end{tabular}

$\mathrm{P}^{\dagger}$ - value calculated by Chi Square Test ${ }^{*}$ - Statistically Significant.

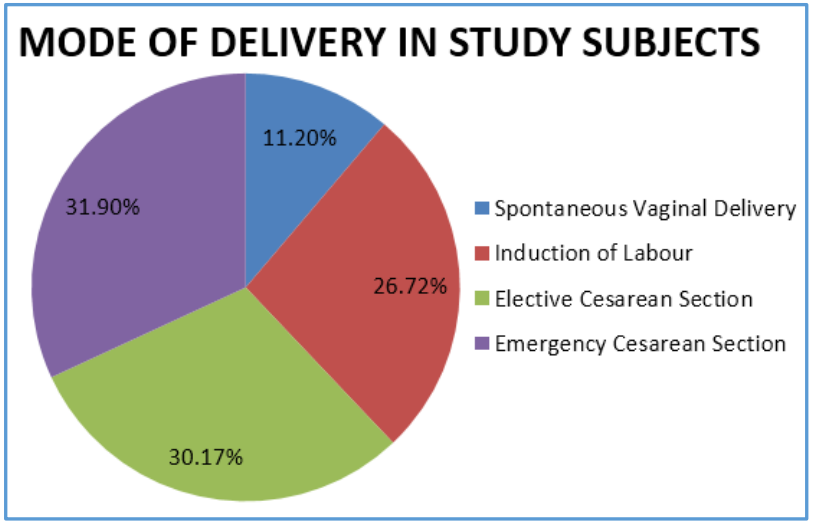

Average age of delivery in study group was much earlier at $36.6 \pm 1.2$ weeks compared to $38.9 \pm 0.6$ weeks in non-FGR group, which could potentially cause prematurity and related complications ( $\mathrm{P}<0.0001)$. Statistically significant differences were observed in the birth weight of FGR group (2105 $\pm 50 \mathrm{gms}$ ) compared to $2850 \pm 107$ gms in non-FGR group with $\mathrm{P}<0.0001$. The same when charted on foetal growth chart showed significant difference of $4.2^{\text {nd }}$ vs. $20.6^{\text {th }}$ centile respectively. APGAR scores also showed statistically significant difference at birth and 5 minutes of life. The same is demonstrated in Table 4.

\begin{tabular}{|c|c|c|c|c|c|c|}
\hline $\begin{array}{c}\text { Sl. } \\
\text { No. }\end{array}$ & $\begin{array}{c}\text { Outcome } \\
\text { at } \\
\text { Birth }\end{array}$ & $\begin{array}{c}\text { Mean of Study } \\
\text { Group } \\
\text { FGR (106) }\end{array}$ & $\begin{array}{c}\text { SD } \\
\text { in } \\
\text { Study Group }\end{array}$ & $\begin{array}{c}\text { Mean in Control } \\
\text { Group } \\
\text { No FGR (114) }\end{array}$ & $\begin{array}{c}\text { SD in } \\
\text { Control } \\
\text { Group }\end{array}$ & P - value \\
\hline 1. & Age at Delivery & $36.6 \mathrm{wks}$ & \pm 1.2 & $38.9 \mathrm{wks}$ & \pm 0.6 & $<0.0001^{*}$ \\
\hline 2. & Birth Weight & 2105 gm & \pm 50 & 2850 gm & \pm 107 & $<0.0001^{*}$ \\
\hline 3. & Centile of weight & $4.2^{\text {nd }}$ centile & \pm 0.4 & $20.6^{\text {th }}$ centile & \pm 2.8 & $<0.0001^{*}$ \\
\hline 4. & APGAR at birth & 6.43 score & \pm 0.21 & 7.96 score & \pm 0.91 & $<0.0001^{*}$ \\
\hline 5. & APGAR at 5 minutes & 7.27 score & \pm 0.36 & 8.64 score & \pm 0.63 & $<0.0001^{*}$ \\
\hline \multicolumn{7}{|r|}{ Table 4. Neonatal Outcomes in Study and Control Group } \\
\hline
\end{tabular}

$\mathrm{P} \ddagger$ - value calculated by Unpaired ' $\mathrm{t}$ ' Test $\left.\right|^{*}$ - Statistically Significant

Table 5 represents 33\% of FGR foetuses (35) had prematurity compared to $5.2 \%$ of non-FGR foetuses (6), and this brings us to a conclusion that statistically significant prematurity is seen in FGR babies ( $\mathrm{P}<0.0001)$. Complications associated with prematurity like RDS $(\mathrm{P}$ -
0.007), NEC (P - 0.03) and ROP (P - 0.04) were found more in FGR babies compared to control group; 12 patients in study group had sepsis $(11.3 \%)$ compared to 3 patients $(2.6 \%)$ in control group, which was significant by Chi Square Fisher exact calculation). 


\begin{tabular}{|c|c|c|c|c|c|}
\hline Sl. No. & Outcome & $\begin{array}{c}\text { Outcome } \\
\text { Characterisation }\end{array}$ & $\begin{array}{c}\text { Study Group } \\
\text { FGR } \\
(\mathrm{N}=106) \\
\end{array}$ & $\begin{array}{c}\text { Control Group } \\
\text { No FGR } \\
(\mathrm{N}=114) \\
\end{array}$ & $P^{\dagger}-$ value \\
\hline \multirow{2}{*}{1.} & \multirow{2}{*}{ Prematurity } & No Prematurity & $71(67 \%)$ & $108(94.7 \%)$ & \multirow{2}{*}{$<0.0001^{*}$} \\
\hline & & Prematurity & $35(33 \%)$ & $6(5.2 \%)$ & \\
\hline \multirow{2}{*}{2.} & \multirow{2}{*}{$\begin{array}{l}\text { Respiratory Distress } \\
\text { Syndrome (RDS) }\end{array}$} & No RDS & $91(85.8 \%)$ & $110(96.4 \%)$ & \multirow{2}{*}{$0.007^{*}$} \\
\hline & & RDS & $15(14.1 \%)$ & $4(3.5 \%)$ & \\
\hline \multirow{2}{*}{3.} & \multirow{2}{*}{ Sepsis } & No Sepsis & $94(88.6 \%)$ & $111(97.3 \%)$ & \multirow{2}{*}{$0.01^{*}$} \\
\hline & & Sepsis & $12(11.3 \%)$ & $3(2.6 \%)$ & \\
\hline \multirow{2}{*}{4.} & \multirow{2}{*}{$\begin{array}{l}\text { Pathological Brain } \\
\text { Scans (PBS) }\end{array}$} & No PBS & $95(89.6 \%)$ & $109(95.6 \%)$ & \multirow{2}{*}{$0.11^{\text {邦 }}$} \\
\hline & & PBS & $11(10.3 \%)$ & $5(4.3 \%)$ & \\
\hline \multirow{2}{*}{5.} & \multirow{2}{*}{$\begin{array}{c}\text { Retinopathy of Prematurity } \\
\text { (ROP)§ }\end{array}$} & No ROP & $96(90.5 \%)$ & $111(97.3 \%)$ & \multirow{2}{*}{$0.04^{*}$} \\
\hline & & ROP & $10(9.5 \%)$ & $3(2.6 \%)$ & \\
\hline \multirow{2}{*}{6.} & \multirow{2}{*}{$\begin{array}{l}\text { Necrotising Enterocolitis } \\
\text { (NEC) }\end{array}$} & No NEC & $99(93.4 \%)$ & $113(99.1 \%)$ & \multirow{2}{*}{$0.03^{*}$} \\
\hline & & NEC & $7(6.6 \%)$ & $1(0.9 \%)$ & \\
\hline \multirow[b]{2}{*}{7.} & \multirow{2}{*}{$\begin{array}{c}\text { Early Neonatal Deaths } \\
\text { (END) } \\
\text { (mortality in first } 7 \text { days) }\end{array}$} & Late Neonates & $94(88.6 \%)$ & $113(99.1 \%)$ & \multirow[b]{2}{*}{$0.001^{*}$} \\
\hline & & Early Neonatal Death & $12(11.3 \%)$ & $1(0.9 \%)$ & \\
\hline \multirow[b]{2}{*}{8.} & \multirow{2}{*}{$\begin{array}{c}\text { Perinatal Mortality } \\
\text { (Still Births + END) } \\
(\mathrm{N}=116)\end{array}$} & Late Neonates & $94(88.6 \%)$ & $113(99.1 \%)$ & \multirow{2}{*}{$<0.0001^{*}$} \\
\hline & & Perinatal Deaths & $22(20.75 \%)$ & $3(0.9 \%)$ & \\
\hline
\end{tabular}

Table 5. Outcomes in NICU in Study and Control Group

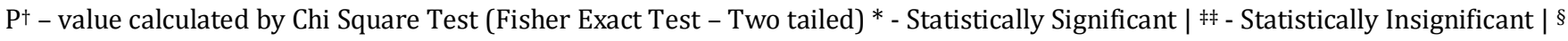
Follow-up at 4 weeks by Ophthalmologist.

\section{DISCUSSION}

Barker and his colleagues reported in several epidemiological and anthropological studies that in foetal life, tissues and organs go through the so-called 'critical' periods of development. These may coincide with periods of rapid cell division. Although, the foetal growth is influenced by its genes, several studies suggest that it is usually limited by intrauterine environment, in particular the nutrients and oxygen received from the mother.[11,12]

Our statistics are in conformation with the results of Andzane D et al,[4] Stanisic Chou T et al[13] and Romo A et al.[14] Few differences have been noted as factors predisposing to FGR are present in higher concentrations in Indian society. More so our hospital deals with patients from low socioeconomic strata, which could cause certain statistical differences when compared with other studies.

Some studies mention that $75 \%$ of all FGR cases are not diagnosed till birth and are only diagnosed retrospectively by neonatal anthropometry.[15] Such cases have not been included in the study, as our main focus was correlation between antenatally diagnosed true FGR and its outcomes. Also to be considered is the fact that Indian babies are constitutionally smaller than babies in the US, keeping this in mind Indian studies have recommended using growth charts prepared for Indian babies,[16] but these have not yet been popularised for use and hence standard charts currently in use have been used in the study.

Sharifzadeh et al in his study found a positive correlation between SGA and low maternal BMI before pregnancy.[17] Albu et al[18] and Andzane D et al[4] have reported similar aetiologic relationships with risk factors as mentioned in our study. Natalija Vedmedovska et al in 2010 described the average GA around 36.3 weeks, which closely resembles the GA in our study group.[19] The rate of elective caesarean section was $30 \%$ in our study, which corresponds to $26.3 \%$ in a study by Andzane et al,[4] but the average GA in the same study was around $39.3 \%$ which is much higher than our study.
Neonatal and post-natal outcomes measured in our study are in close agreement to the findings of Visentin et al[2] and Gomez et al.[3] They too reported a higher incidence of complications and the need for caesarean section in the FGR group with statistically comparable differences in the nonFGR group. Visentin et al also reported statistically significant non-reassuring foetal pattern on CTG in foetuses affected with FGR. [2]

\section{CONCLUSION}

Foetal Growth Restriction is a major obstetric problem. It is a major cause of perinatal mortality and morbidity, and it is associated with several health problems throughout life. There is recent emerging evidence in the form of 'developmental origins of adult disease,' the Barker hypothesis which proposes that certain diseases originate through adaptations of the foetus when it is undernourished. These adaptations may be cardiovascular, metabolic or endocrine, and they may permanently change the structure and function of the body, increasing coronary heart disease risk factors such as hypertension, type 2 diabetes mellitus, insulin resistance and hyperlipidaemia. It is not just the foetus, but also the mother which is adversely affected by FGR in terms of operative interference and psychological upset. An assessment of risk factors and knowledge of probable outcomes can help us in understanding FGR better and to offer better counselling to mothers whose foetuses are affected with FGR. Further research is essential to evaluate the long-term effects of FGR and to explore therapeutic options to reduce the end effects of FGR on the foetus.

\section{ACKNOWLEDGEMENT}

The authors sincerely thank Dr. M. Srinivas (Dean, ESIC Medical College, Hyd), Dr. T. Madhuri (Academic Registrar, ESIC MC) and Dr. M. Ashwin Kumar (In-Charge, Medical Education Unit, ESICMC), for their continued efforts in our academic growth and enlightenment. The authors also thank the Department of Paediatrics, ESICMC for their co-operation and support. 


\section{REFERENCES}

[1] RCOG. The investigation and management of the small for gestational age foetus. Royal college of obstetricians and gynaecologists. Green top Guideline 2014;31(2):1-34.

[2] Visentin S, Cavallin F, Zanardo V, et al. Neonatal outcome in intrauterine growth restricted and small for gestational age foetuses. Ultrasound in Obstetrics \& Gynecology 2010;36:54-167.

[3] Roig MG, Mazarico E, Sabria J, et al. Perinatal outcomes in gestations with intrauterine growth restriction and small for gestational age foetuses, admitted to neonatal unit. Ultrasound in Obstetrics \& Gynecology 2010;36:54-167.

[4] Andzane D, Gapatins I, Miskova A. Intrauterine growth restriction: distribution, risk factors, management of labour and outcome. Int J Reprod Contracept Obstet Gynecol 2015;4(4):1117-21.

[5] Quinton A, Cook C, Peek M. The prediction of the small for gestational age foetus with the head circumference to abdominal circumference (HC/AC) ratio: a new look at an old measurement. Sonography 2015;2(2):27-31.

[6] Jang DG, Jo YS, Lee SJ, et al. Perinatal outcomes and maternal clinical characteristics in IUGR with absent or reversed end-diastolic flow velocity in the umbilical artery. Arch Gynecol Obstet 2011;284(1):73-8.

[7] Cox P, Marton T. Pathological assessment of intrauterine growth restriction. Best Practice and Research, Clinical Obstetrics and Gynaecology 2009;23(6):751-64.

[8] Pallotto EK, Kilbride HW. Perinatal outcome and later implications of intrauterine growth restriction. Clin Obstet Gynecol 2006;49(2):257-69.

[9] Bhimarao, Nagaraju RM, Bhat V, et al. Efficacy of transcerebellar diameter/abdominal circumference versus head circumference/abdominal circumference in predicting asymmetric intrauterine growth retardation. Journal of Clinical and Diagnostic Research 2015;9(10):1-5.
[10] Kramer MS, Platt RW, Wen SW, et al. A new and improved population-based Canadian reference for birth weight for gestational age. Pediatrics 2001;108(2):E35.

[11] Barker DJ. Adult consequences of fetal growth restriction. Clinical Obstetrics and Gynecology 2006;49(2):270-83.

[12] Barker DJ. In utero programming of cardiovascular disease. Theriogenology 2000;53(2):555-74.

[13] Chou ST, Toohey JS. Foetal growth disorders. In: Di Saia PJ, Chaudhuri G, Giudice LC, et al. (eds) Women's health review: a clinical update in obstetricsgynecology. Philadelphia, PA: Elsevier Saunders 2012:97-100.

[14] Romo A, Carceller R, Tobajas J. Intrauterine growth retardation (IUGR): epidemiology and etiology. Pediatr Endocrinol Rev 2009;6(3):332-6.

[15] Figueras F, Gardosi J. Intrauterine growth restriction: new concepts in antenatal surveillance, diagnosis, and management. Am J Obstet Gynecol 2011;204(4):288-300.

[16] Hemasree K, Agrawal S, Geetha K, et al. Gestational age-specific centile charts for anthropometry at birth for south Indian infants. Indian Pediatrics 2012;49:199-202.

[17] Sharifzadeh F, Kashanian M, Jouhari S, et al. Relationship between pre-pregnancy maternal BMI with spontaneous preterm delivery and birth weight. J Obstet Gynaecol 2015;35(4):354-7.

[18] Albu AR, Anca AF, Horhoianu VV, et al. Predictive factors for intrauterine growth restriction. J Med Life 2014;7(2):165-71.

[19] Vedmedovska N, Rezeberga D, Teibe $U$, et al. Placental pathology in fetal growth restriction. Eur J Obstet Gynecol Reprod Biol 2011;155(1):36-40. 